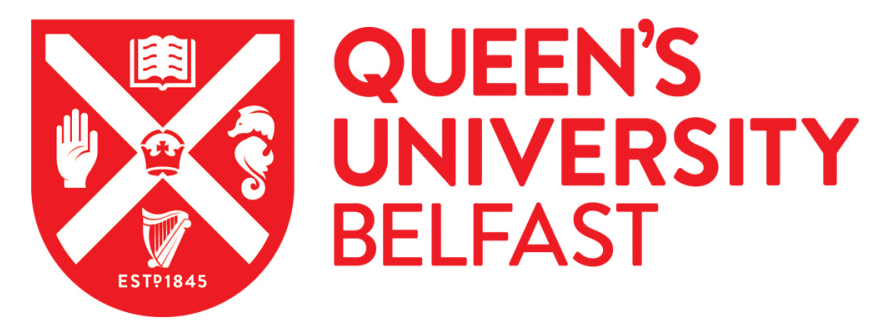

\title{
Iron nutrition of peanut enhanced by mixed cropping with maize: Possible role of root morphology and rhizosphere microflora
}

Zuo, Y. M., Li, X. L., Cao, Y. P., Zhang, F. S., \& Christie, P. (2003). Iron nutrition of peanut enhanced by mixed cropping with maize: Possible role of root morphology and rhizosphere microflora. Journal of Plant Nutrition, 26(10-11), 2093-2110.

Published in:

Journal of Plant Nutrition

Queen's University Belfast - Research Portal:

Link to publication record in Queen's University Belfast Research Portal

\section{General rights}

Copyright for the publications made accessible via the Queen's University Belfast Research Portal is retained by the author(s) and / or other copyright owners and it is a condition of accessing these publications that users recognise and abide by the legal requirements associated with these rights.

Take down policy

The Research Portal is Queen's institutional repository that provides access to Queen's research output. Every effort has been made to ensure that content in the Research Portal does not infringe any person's rights, or applicable UK laws. If you discover content in the Research Portal that you believe breaches copyright or violates any law, please contact openaccess@qub.ac.uk. 


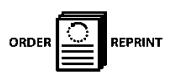

JOURNAL OF PLANT NUTRITION

Vol. 26, Nos. 10 \& 11, pp. 2093-2110, 2003

\title{
Iron Nutrition of Peanut Enhanced by Mixed Cropping with Maize: Possible Role of Root Morphology and Rhizosphere Microflora
}

\author{
Yuanmei Zuo, ${ }^{1}$ Xiaolin $\mathrm{Li},{ }^{1}$ Yiping Cao, ${ }^{1}$ Fusuo Zhang, ${ }^{1, *}$ \\ and Peter Christie ${ }^{1,2}$ \\ ${ }^{1}$ Department of Plant Nutrition, College of Resources and \\ Environmental Sciences, China Agricultural University, \\ Beijing, China \\ ${ }^{2}$ Agricultural and Environmental Science Department, Queen's \\ University Belfast, Belfast, UK
}

\begin{abstract}
Field observations have indicated that Fe deficiency chlorosis symptoms in peanut are more severe and widespread in monoculture than intercropped with maize in calcareous soils of northern China. Here we report a pot experiment that investigated the mechanisms underlying the marked improvement in Fe nutrition of peanut grown in mixture with maize. Iron deficiency chlorosis occurred in the young leaves of peanut
\end{abstract}

${ }^{*}$ Correspondence: Professor F. S. Zhang, Department of Plant Nutrition, College of Resources and Environmental Sciences, China Agricultural University, Beijing 100094, China; Fax: +86 10 62891016; E-mail: zhangfs@cau.edu.cn.

2093

DOI: $10.1081 /$ PLN-120024267

Copyright (C) 2003 by Marcel Dekker, Inc.
0190-4167 (Print); 1532-4087 (Online) www.dekker.com 


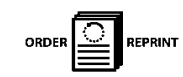

in monoculture and was particularly obvious at the flowering stage, while the young leaves of peanut grown in mixture with maize remained green throughout the experiment. The chlorophyll and HCl-extractable Fe concentrations in young leaves of peanut grown in mixture were much higher than those in monoculture, indicating that maize may have markedly improved the peanut Fe nutrition. Growth in mixture was associated with greatly altered root morphology and microbial populations in the rhizosphere of peanut. Visual observation of peanut roots in monoculture showed that they were larger in diameter and shorter than those in mixture. Moreover, peanut roots in mixture with maize produced more lateral roots and had increased root length compared with plants in monoculture. Peanut grown together with maize showed obvious rhizodermal transfer cells in the subapical root zone, but cells with cell wall ingrowths were poorly developed in peanut in monoculture. Mixed culture resulted in a significantly decreased abundance of bacteria in the rhizosphere of peanut compared with monoculture, and electron microscope observations indicated that this was associated with a thicker mucigel layer on the root surface of peanut in mixture with maize. Several root morphological and rhizosphere microbial factors may thus have contributed to the improvement in Fe nutrition of peanut in mixed culture.

Key Words: Peanut; Maize; Mixed cropping; Iron; Root morphology; Rhizosphere; Microflora.

\section{INTRODUCTION}

Iron deficiency chlorosis in peanut (Arachis hypogaea L.) represents a serious economic problem in peanut producing areas on calcareous soils in northern China. Peanut is the major oilseed crop in China, accounting for $30 \%$ of the cropped area and $30 \%$ of the total oilseed production. Iron deficiency chlorosis is common in peanut grown in monocropping systems in calcareous soils, but is much less commonly observed in peanut/maize intercropping systems. There is considerable interest in devising practical agronomic approaches for the correction or avoidance of Fe deficiency in peanut crops and intercropping has become the most common cropping system for peanut production in northern China.

Recent research has indicated that the improvement in Fe nutrition of peanut intercropped with maize may be attributable, at least in part, to rhizosphere interactions between peanut and maize. ${ }^{[1]}$ However, the detailed factors leading to improved Fe nutrition and facilitation of enhanced uptake of Fe by the maize rhizosphere effect are still poorly understood. Peanut displays 


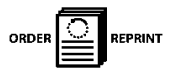

Fe Nutrition of Peanut Intercropped with Maize

"Strategy I" mechanisms for responding to Fe stress in which increased reductase activity occurs on the surface of the plant roots in addition to release of protons and reductants from the roots. This strategy might not succeed in buffered calcareous soils even if Fe-efficient varieties of peanut were used in an attempt to overcome the Fe chlorosis problem. ${ }^{[2,3]}$ The Fe(III) reducing capacity and morphology of peanut roots are closely related to Fe uptake. A hypothesis suggested to account for re-greening of plants is enhanced root growth, especially at higher soil temperatures, so that the roots make contact with more $\mathrm{Fe}$, and the enhanced number of roots make more $\mathrm{Fe}$ available for uptake by reducing more $\mathrm{Fe}^{3+}$ to $\mathrm{Fe}^{2+} \cdot{ }^{[4]}$ However, most studies on this topic have been conducted in hydroponic conditions with Fe being supplied mostly as Fe chelates in monoculture. In contrast, there is little published information on how the $\mathrm{Fe}$ (III) reducing capacity and morphology of roots are related to peanut Fe nutrition in soil, and how this may be affected by intercropping with maize.

Micro-organisms can play an important role in plant nutrition. ${ }^{[5,6]}$ Different plant species $^{[7,8]}$ or genotypes within a species ${ }^{[9]}$ can influence microbial populations and species composition of the microbial community in the rhizosphere to different extents. It is often assumed that differences in the composition of microbial populations are due to quantitative and/or qualitative differences in root exudation. Interactions are likely to be more important in nutrient-deficient soils and the influence of root exudates of maize on micro-organisms and peanut Fe nutrition requires further study. The objectives of the present work were to (i) identify the effects of peanut intercropped with maize on changes in morphology and physiological reactions of peanut roots to Fe-deficiency stress; (ii) assess the influence of these changes on the Fe nutritional status of peanut plants intercropped with maize on a low-Fe calcareous soil; and (iii) preliminary identify the effects of intercropping peanut with maize on microbial populations in the peanut rhizosphere and review the available information on the influence of the rhizosphere microflora on the Fe nutrition of peanut intercropped with maize.

\section{MATERIALS AND METHODS}

\section{The Experimental Soil}

The calcareous sandy soil used in the experiment was collected from the plough layer of a farm meadow near Beijing, north China $\left(39^{\circ} 40^{\prime} \mathrm{N}\right.$, $116^{\circ} 15^{\prime} \mathrm{E}$ ), and had the following properties: $\mathrm{pH}$ (in water) $7.8, \mathrm{CaCO}_{3}$ $9.25 \%$, organic matter $0.39 \%$, DTPA-Fe $4.22 \mathrm{mg} \mathrm{kg}^{-1}$, sand $92.6 \%$, and 


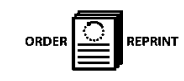

bulk density $1.3 \mathrm{~g} \mathrm{~cm}^{-3}$. The soil was air-dried, sieved $(<2 \mathrm{~mm})$ and amended with basal nutrients at the following rates $\left(\mathrm{mg} \mathrm{kg}^{-1}\right)$ : $\mathrm{N} 150$ as $\mathrm{Ca}\left(\mathrm{NO}_{3}\right)_{2} ; \mathrm{P} 150$ as $\mathrm{KH}_{2} \mathrm{PO}_{4} ; \mathrm{Mg} 50$ as $\mathrm{MgSO}_{4} ; \mathrm{Zn} 5$ as $\mathrm{ZnSO}_{4}$; and $\mathrm{Cu} 5$ as $\mathrm{CuSO}_{4}$.

\section{Plant Growth}

The experiment consisted of 3 treatments with 20 replicates per treatment and 4 replicates at each harvest for 5 different sampling times. At 40 days of peanut planting, the first harvest preceded the onset of Fe deficiency chlorosis symptoms in peanut in monoculture, after which samples were taken $3,6,10$, and 14 days after the development of Fe-deficiency chlorosis of peanut at 45 days. The treatments were peanut monoculture, maize monoculture, and peanut/maize mixture. Peanut (A. hypogaea L. cv. Haihuang) and maize (Zea mays L. cv. Danyu) seeds of uniform size were surface sterilized in $5 \%$ (v/v) $\mathrm{H}_{2} \mathrm{O}_{2}$ for $30 \mathrm{~min}$, washed with deionized water and germinated at $25^{\circ} \mathrm{C}$ in the dark in sterile coarse quartz sand $(2 \mathrm{~mm}$ diameter) moistened with saturated $\mathrm{CaSO}_{4}$ solution. After 2 days, six germinated seeds of peanut and three germinated seeds of maize were planted per pot. Each pot contained $10 \mathrm{~kg}$ of sandy soil. The plants were grown at $26 / 20^{\circ} \mathrm{C}$ and $14 / 10 \mathrm{~h}$ day/night cycles with a relative humidity of $70-75 \%$. Soil water content was maintained at about $80 \%$ of field capacity by weight on a daily basis. The very sandy calcareous soil is easily penetrated by plant roots and readily absorbs water but has poor water retention capacity. The ratio of peanut: maize was $2: 1$ in the mixed culture treatment. The ratio of peanut was $1: 1$ in the monoculture and mixed culture treatment.

\section{Plant Analysis}

The peanut plants were harvested and separated into young leaves, primary leaves, stems, and roots. Leaf samples were washed with $0.1 \%$ (v/v) $\mathrm{HCl}$ followed by distilled water. A leaf subsample was taken for measurement of $\mathrm{HCl}$-extractable Fe (so-called "active Fe") according to the procedure of Takkar and Kaur. ${ }^{[10]}$ The chlorophyll content of fresh peanut leaves was determined spectrophotometrically according to Witham et al. ${ }^{[1]}$ Root samples were washed with distilled water. The remaining samples of leaf tissue and all roots were dried at $80^{\circ} \mathrm{C}$ for $48 \mathrm{~h}$ and ground. After ashing at $550^{\circ} \mathrm{C}$ for about $10 \mathrm{~h}$ and dissolving the ash in $1: 30(\mathrm{v} / \mathrm{v}) \mathrm{HNO}_{3}$, the concentrations of total $\mathrm{Fe}$ in leaves and roots were determined by atomic absorption spectrophotometry. 


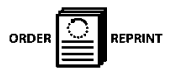

Fe Nutrition of Peanut Intercropped with Maize

\section{Root Morphology Parameters}

A fresh root subsample was taken for measurement of root radius and root length according to the root intersect method of Newman. ${ }^{[12]}$ Root length was estimated as follows:

$$
L=\frac{11}{14} \times N \times 2
$$

where $N=$ the number of root/line intersections.

Root radius was characterized as follows:

$$
R=\left(\frac{\mathrm{FW}}{L} \times \pi\right)^{1 / 2}
$$

where $\mathrm{FW}=$ fresh weight of roots and $L=$ total root length of the plant.

\section{Measurement of Fe(III) Reduction Rate}

The roots of two peanut plants from monoculture and mixture, collected at the five harvest times during the occurrence of Fe deficiency chlorosis in peanut in monoculture $(0,3,6,10,14$ days), were immersed in saturated $\mathrm{CaSO}_{4}$ solution for $30 \mathrm{~min}$, washed with deionized water and then transferred to a $250-\mathrm{mL}$ black Erlenmeyer flask containing $200 \mathrm{~mL}$ of nutrient solution with $0.01 \mathrm{~mol} \mathrm{~L}^{-1} \mathrm{MES}$ buffer (pH 6) and $0.2 \mathrm{mmol} \mathrm{L}^{-1}$ ferrozine (disodium salt of 3-(2-pyridyl-5,6-bis(4-phenylsulfonic acid)-1,2,4-triazine). Iron was supplied as $0.5 \mathrm{mmol} \mathrm{L}^{-1} \mathrm{Fe}(\mathrm{III}) \mathrm{EDTA}$. Iron reduction was measured after $2 \mathrm{~h}$ by measuring the absorbance of the solution at $520 \mathrm{~nm}$. Root fresh weight was recorded and reduction rates were calculated on root weight basis. ${ }^{[13]}$

\section{Characteristics of Rhizosphere Bacteria and Occurrence of Mucigel Layer}

Free-hand transverse sections were prepared from the fresh root tip and $2 \mathrm{~mm}$ behind the tip. The sections were fixed for electron microscopy with $4 \%$ formaldehyde and $2.5 \%$ glutaraldehyde ( $\mathrm{pH} 7.2$ ) for $4 \mathrm{~h}$ at room temperature, and then washed with phosphate buffer solution $\left(100 \mathrm{mmol} \mathrm{L}^{-1}, \mathrm{pH} 7.2\right)$, stained with $1 \%$ osmic acid and postfixed for $2 \mathrm{~h}$. After dehydration by an ethanol series, the samples were embedded in Epon 812 Spurr's resin. The samples were cut into ultrathin sections with a diamond knife and then observed under an electron microscope at $60 \mathrm{kV}$. The microorganisms present were observed and the occurrence or absence of a mucigel layer was recorded. 


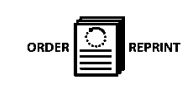

\section{Rhizosphere Bacterial Population}

Rhizosphere bacterial counts were conducted to determine whether the bacterial counts of the roots corresponded with the microscopical observations. The rhizosphere soil was sampled by lifting peanut plants from the soil and shaking gently. Soil still adhering to the roots was considered to be rhizosphere soil. About $10 \mathrm{~g}$ fresh weight of soil was sampled separately after removing all visible root pieces and mixing the soil thoroughly. Soil samples $(10 \mathrm{~g})$ were placed in $90 \mathrm{~mL}$ sterilized distilled water in Erlenmeyer flasks and incubated under continuous shaking at room temperature for $15 \mathrm{~min}$. The flasks were then allowed to stand for about $1 \mathrm{~h}$ to allow the soil to settle. A dilution series $\left(10^{-4}\right.$ to $\left.10^{-8}\right)$ was then prepared from the supernatant. From each dilution step, a $0.1-\mathrm{mL}$ aliquot of solution was plated on to agar medium and incubated at $28-30^{\circ} \mathrm{C}$ for $48 \mathrm{~h}$. The numbers of bacterial colonies from 4 replicate samples were counted. The agar growth medium for enumeration of bacteria contained $0.4 \mathrm{~g} \mathrm{~K} \mathrm{~K}_{2} \mathrm{HPO}_{4}, 0.5 \mathrm{~g}$ $\left(\mathrm{NH}_{4}\right)_{2} \mathrm{HPO}_{4}, 0.05 \mathrm{~g} \mathrm{MgSO}_{4} \cdot 7 \mathrm{H}_{2} \mathrm{O}, 0.1 \mathrm{~g} \mathrm{MgCl}_{2}, 0.01 \mathrm{~g} \mathrm{FeCl}, 0.1 \mathrm{~g} \mathrm{CaCl}$, $1 \mathrm{~g}$ peptone, $1 \mathrm{~g}$ yeast extract, $18 \mathrm{~g}$ agar, $250 \mathrm{~mL}$ soil extract, and $750 \mathrm{~mL}$ double-distilled water.

\section{Statistical Analysis}

There were 3 treatments $\times 5$ harvests $\times 4$ replicates, giving a total of 60 pots arranged in a fully randomized block design. Root reducing capacity data are presented for all 5 harvests and all other data are from the final harvest only. At each harvest, treatment means $(n=4)$ for the different culture types (monoculture vs. mixture) were compared using Student's paired $t$-test at the $5 \%$ level.

\section{RESULTS}

\section{Iron Deficiency Symptoms}

Iron deficiency chlorosis in the young leaves of peanut in monoculture appeared before the flowering stage and was very obvious by the flowering stage. Plants grown in mixture with maize remained green throughout the growing period. Thus, growth in mixture with maize markedly improved the Fe nutrition of the peanut plants. 


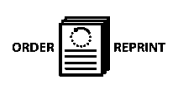

Fe Nutrition of Peanut Intercropped with Maize

\section{Plant Growth}

Mixed culture with maize did not affect peanut shoot yield but increased the root yield 1.8-fold compared with monoculture. At the same time, mixed culture also enhanced the growth of maize. The shoot and root yield were increased 1.1-fold and 1.2-fold respectively (Table 1).

\section{Plant Fe Concentrations}

The Fe concentrations in young leaves, primary leaves, stem, and roots of peanut plants grown in mixture with maize were generally higher than those of plants in monoculture (Table 2). Mixed culture with maize in pots also enhanced the chlorophyll and $\mathrm{HCl}$-extractable $\mathrm{Fe}$ concentrations in young leaves of peanut (Table 3 ).

\section{Reducing Capacity of Peanut Roots}

The reducing capacity of peanut roots in monoculture increased in conjunction with the appearance of Fe deficiency chlorosis symptoms in young leaves. The maximum Fe(III)-reducing capacity of roots in monoculture occurred at 6 days and subsequently decreased rapidly. By the fourteenth day, when peanut showed severe $\mathrm{Fe}$ deficiency in monoculture, the reducing capacity of the roots was lower than that of peanut that had no Fe deficiency symptoms from the mixed culture system. In contrast, the reducing capacity of peanut roots grown in mixture with maize increased very slowly, and was

Table 1. Shoot and root dry matter yield at final harvest of peanut and maize in monoculture and in mixture $\left(\mathrm{g} \mathrm{DM} \mathrm{pot}^{-1}\right)$.

\begin{tabular}{lccc}
\hline Crops & Monoculture & Mixture & Significance $^{\mathrm{a}}$ \\
\hline Peanut & & & \\
$\quad$ Shoots & $18.0(1.1)^{\mathrm{b}}$ & $21.8(2.2)$ & $\mathrm{ns}$ \\
$\quad$ Roots & $2.7(0.3)$ & $4.9(0.8)$ & $*$ \\
Maize & & & \\
$\quad$ Shoots & $35.84(1.01)$ & $42.4(2.11)$ & $*$ \\
$\quad$ Roots & $37.03(1.09)$ & $45.5(2.4)$ & $*$ \\
\hline
\end{tabular}

${ }^{a}$ Significance of difference between monoculture and mixture by paired $t$-test; ${ }^{*}, P<0.05$; ns, not significant.

${ }^{\mathrm{b}}$ Values in parentheses are standard errors of the mean $(n=4)$. 


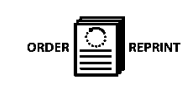

Table 2. Total Fe concentration at final harvest of peanut in monoculture and in mixture with maize.

\begin{tabular}{llcc}
\hline & \multicolumn{3}{c}{ Total Fe concentration $\left(\mathrm{mg} \mathrm{kg}^{-1} \mathrm{DM}\right)$} \\
\cline { 2 - 4 } Peanut component & Monoculture & Mixture & Significance $^{\mathrm{a}}$ \\
\hline Young leaves & $102.9(5.6)^{\mathrm{b}}$ & $143.8(3.5)$ & $*$ \\
Primary leaves & $158.4(3.3)$ & $178.2(4.4)$ & $*$ \\
Stem & $218.7(8.6)$ & $349.3(20.0)$ & $*$ \\
Roots & $878.0(16.5)$ & $1023.8(43.5)$ & $*$ \\
\hline
\end{tabular}

${ }^{\text {a }}$ Significance of difference between monoculture and mixture by paired $t$-test; $*, P<0.05 ;$ ns, not significant.

${ }^{\mathrm{b}}$ Values in parentheses are standard errors of the mean $(n=4)$.

greater than that of peanut roots from monoculture after the appearance of $\mathrm{Fe}$ deficiency chlorosis in monoculture at 10 days (Fig. 1).

\section{Peanut Root Morphology}

Mixed culture increased the dry weight of peanut roots and the main root length. Growth in mixture also increased the numbers and length of lateral roots and the specific root length of peanut, and decreased the root radius (Table 4). Peanut roots from mixed culture showed rhizodermal transfer cells in the subapical root zone. Epidermal cells developed wall ingrowths on the whole cell wall and plasmalemma that were characteristic of transfer cells, whereas transfer cells were poorly developed in peanut roots from monoculture [Fig. 2(a) and (b)].

Table 3. Concentrations of $\mathrm{HCl}$-extractable $\mathrm{Fe}$ and chlorophyll in young and primary leaves at harvest of peanut grown in monoculture and in mixture with maize.

\begin{tabular}{|c|c|c|c|c|}
\hline \multirow[b]{2}{*}{ Culture type } & \multicolumn{2}{|c|}{$\begin{array}{l}\text { HCl-extractable Fe } \\
\left(\mathrm{mg} \mathrm{kg}^{-1} \mathrm{FW}\right)\end{array}$} & \multicolumn{2}{|c|}{ Chlorophyll ( $\left.\mathrm{mg} \mathrm{g}^{-1} \mathrm{FW}\right)$} \\
\hline & Young leaves & Primary leaves & Young leaves & Primary leaves \\
\hline Ionoculture & $20.6(1.1)^{\mathrm{a}}$ & $46.6(0.6)$ & $0.6(0.05)$ & $1.4(0.1)$ \\
\hline Mixture & $39.6(1.0)$ & $52.9(2.8)$ & $1.9(0.05)$ & $2.7(0.2)$ \\
\hline Significance ${ }^{b}$ & $*$ & $\mathrm{~ns}$ & * & * \\
\hline
\end{tabular}

${ }^{a}$ Values in parentheses are standard errors of the mean $(n=4)$.

${ }^{\mathrm{b}}$ Significance of difference between monoculture and mixture by paired $t$-test; *, $P<0.05 ;$ ns, not significant. 


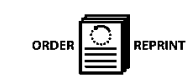

Fe Nutrition of Peanut Intercropped with Maize

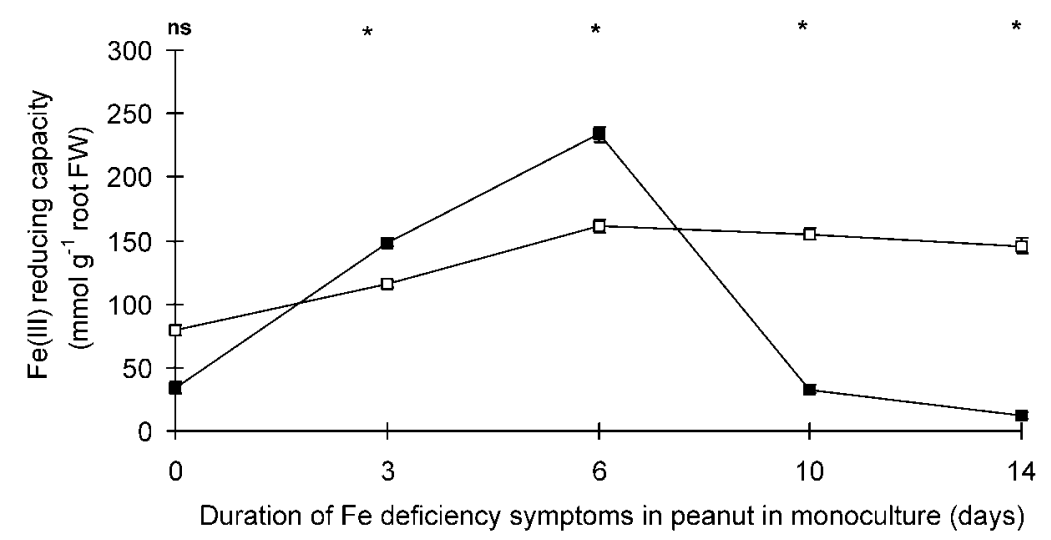

Figure 1. Reducing capacity of peanut roots in monoculture and mixture during the period of Fe deficiency symptoms in peanut in monoculture. Significance of difference between monoculture and mixture by paired $t$-test: ${ }^{*}, P<0.05$; ns, not significant. Culture type: $\mathbf{\square}$, monoculture; $\square$, mixture. Bars: standard error of the mean $(n=4)$.

\section{Micro-organisms in the Peanut Rhizosphere and Occurrence of a Mucigel Layer}

Mixed culture had a marked effect on bacterial abundance in the rhizosphere of peanut. Plants that were grown with maize had fewer bacteria in the rhizosphere compared with monoculture (Fig. 3). There were few bacterial

Table 4. Root morphology at harvest of peanut grown in monoculture and in mixture with maize.

\begin{tabular}{|c|c|c|c|}
\hline Morphological parameter & Monoculture & Mixture & Significance $^{\mathrm{a}}$ \\
\hline $\begin{array}{l}\text { Length of main roots } \\
\left(\mathrm{cm} \text { plant }^{-1}\right)\end{array}$ & $19.2(1.1)^{\mathrm{b}}$ & $30.1(1.8)$ & * \\
\hline $\begin{array}{l}\text { Length of lateral roots } \\
\left(\mathrm{cm} \mathrm{root}^{-1}\right)\end{array}$ & $1.6(0.4)$ & $4.7(0.4)$ & * \\
\hline $\begin{array}{l}\text { Number of lateral roots } \\
\quad\left(\text { no. plant }{ }^{-1}\right)\end{array}$ & $18.0(1.5)$ & $34.0(9.3)$ & * \\
\hline Specific root length $\left(\mathrm{cm} \mathrm{g}^{-1} \mathrm{FW}\right)$ & $324.3(49.3)$ & $614.2(64.2)$ & * \\
\hline Root radius $\left(\times 10^{-2} \mathrm{~cm}\right)$ & $4.5(0.3)$ & $3.1(0.2)$ & * \\
\hline
\end{tabular}

${ }^{\text {a }}$ Significance of difference between monoculture and mixture by paired $t$-test; $*, P<0.05$; ns, not significant.

${ }^{\mathrm{b}}$ Values in parentheses are standard errors of the mean $(n=4)$. 


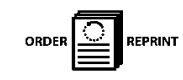

2102

Zuo et al.

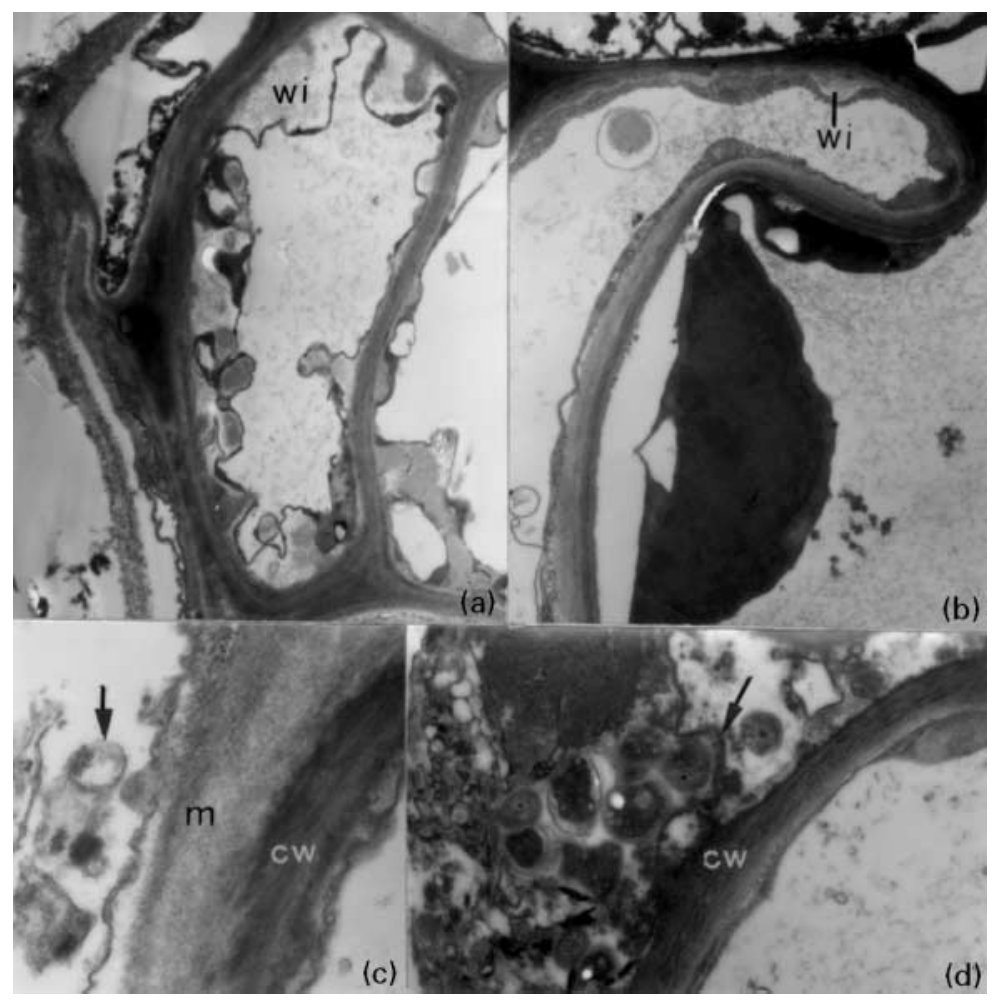

Figure 2. Electron micrograph of peanut root morphology and bacterial colonies and occurrence of mucigel on the root surfaces of peanut in monoculture and mixture. (a) Clear epidermal transfer cell with wall ingrowth (wi) located $2 \mathrm{~mm}$ behind the root tip of peanut in mixture with maize $(5000 \times)$, (b) faint epidermal transfer cell with wall ingrowth (wi) located $2 \mathrm{~mm}$ behind the root tip of peanut in monoculture $(5000 \times)$, (c) thicker mucigel layer on cell surface $2 \mathrm{~mm}$ behind the root tip (m) and fewer bacterial colonies on the root cell surface (arrow) of peanut intercropped with maize; cell wall denoted by cw $(10,000 \times)$, and (d) abundant bacterial colonies on the root surfaces of peanut in monoculture (arrow) and no discernible mucigel layer; cell wall denoted by cw $(10,000 \times)$.

colonies on the surface of mixed-culture peanut roots [Fig. 2(c), arrow], and the mucigel layer on the cell surface of roots of peanut grown with maize was thicker according to electron microscopic observation [Fig. 2(c), m]. In contrast, there were numerous bacterial colonies on the cell surfaces of peanut roots in monoculture [Fig. 2(d), arrow], and no mucigel layer was observed on the surfaces of the roots. 


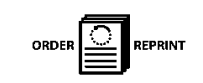

Fe Nutrition of Peanut Intercropped with Maize

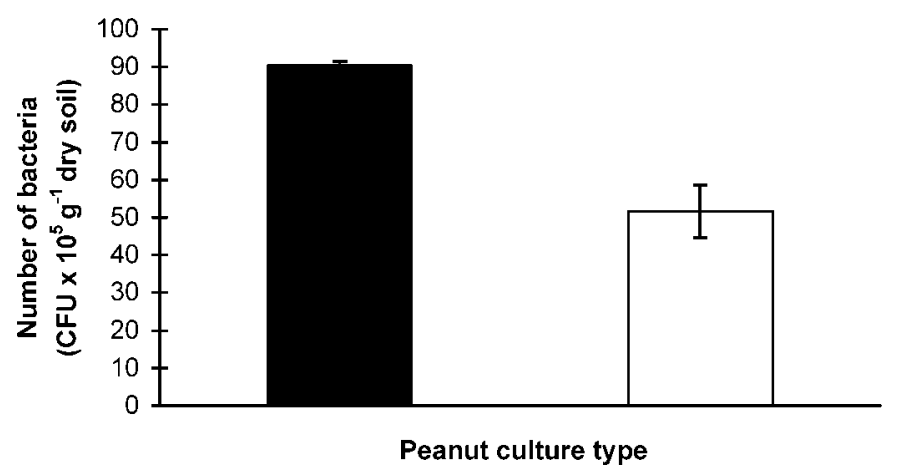

Figure 3. Peanut rhizosphere bacterial counts (CFU, colony forming units) in monoculture and mixture with maize. Culture type: $\mathbf{\square}$, monoculture; $\square$, mixture. Culture types were siginificantly different $(P<0.05$ by paired $t$-test). Bars: standard error of the mean $(n=4)$.

\section{DISCUSSION}

\section{Role of Root Morphology of Peanut Intercropped with Maize in Improvement of Peanut Fe Nutrition}

The widespread problem of Fe deficiency chlorosis in dicotyledonous plants in calcareous soils of arid and semiarid regions was reflected in the peanuts grown in monoculture in our glasshouse experiment. Our results clearly show that the incidence of chlorosis could be eliminated when peanut was grown in mixture with maize. Mixed culture also increased the $\mathrm{HCl}-$ extractable $\mathrm{Fe}$ and chlorophyll concentrations in young peanut leaves as would be expected from the improved visual appearance of the plants (Tables 2 and 3). The maize could not only improve Fe nutrition of peanut, but also the growth of maize could be enhanced by intercropping culture. The results showed that intercropping system of maize and peanut had great intercropping advantage for both crops growth (Table1). Peanut and maize have two distinct root responses to Fe deficiency stress. Peanut displays Strategy I mechanisms. Under conditions of Fe deficiency, reductase activity is increased and release of protons and reductants from the roots is enhanced. In calcareous soils, such as that used in our work, the high $\mathrm{pH}$ and large bicarbonate buffering capacity may render this strategy ineffective. ${ }^{[2,14,15]}$ Maize, on the other hand, is characterized as a "Strategy II" plant, and responds to Fe deficiency by synthesising and releasing phytosiderophores which are able to form very stable complexes with Fe(III) in the soil. ${ }^{[16-19]}$ Our data indicate that in mixed 


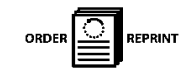

culture maize not only acquired adequate Fe to meet its own demand, but also improved the Fe status of associated peanut.

Most Fe deficiency occurs on high $\mathrm{pH}$ soils, especially on calcareous soils with marginal levels of available Fe. Poor conditions that limit root development and subsequent $\mathrm{Fe}$ uptake will result, either directly or indirectly, in Fe chlorosis of Fe-inefficient plants. Visual observation of the roots of peanut plants grown in monoculture showed few fibrous or lateral roots, and roots were larger in diameter and shorter than those of peanut plants grown in mixture (Table 4). Because of decreased root diameter and increased number of branch roots in mixed culture, specific root length (root length/root weight) was higher. Moreover, roots of peanut in mixture with maize produced more lateral roots than those grown in monoculture. The root tip regions of young lateral roots have been reported to be more active than other root areas in Fe reduction ${ }^{[20]}$ and proton extrusion. ${ }^{[21,22]}$ It is therefore conceivable that the higher exudation of Fe-reducing and Fe-chelating compounds by peanut roots reported here may have been concomitant with greater root branching and/or a larger production of lateral roots for plants in mixed culture. Increased root branching would in turn increase the number of possible protected microsites at the root/soil interface, which are considered essential for maintenance of Fe-mobilizing (reducing and chelating) compounds in their active form. ${ }^{[23,24]}$

In our experiment the peanut roots in the mixed cropping system produced rhizodermal transfer cells in the subapical root zone. In addition, the epidermal cells developed wall ingrowths on the whole cell wall and plasmalemma that were characteristic of transfer cells, whereas transfer cells were rarely observed in the roots of peanut plants that were grown as monocrops [Fig. 2(a) and (b)]. This observation was inconsistent with root transfer cell formation of Strategy I plants induced by Fe deficiency. ${ }^{[25]}$ However, the calcareous soil may provide latent Fe deficiency growth conditions for peanut plants. This is further supported by studies on sugar beet in which root hair and transfer cell formation was induced during latent Fe deficiency without the development of chlorosis symptoms. Transfer cells are also observed in soil-grown plants such as sunflower or chickpea. ${ }^{[26]}$ Thus the efficiency of these cells in adaptive Fe stress responses would explain, at least in part, the observation that symptoms of Fe deficiency chlorosis in sugar beet is rarely observed under field conditions, even on highly calcareous soils. ${ }^{[27]}$ Our observations indicate that the transfer cells of peanut roots in mixture with maize may have facilitated much greater $\mathrm{Fe}$ uptake than in monoculture.

Our results emphasize the great differences that can occur in both morphological and physiological characteristics of peanut roots in monoculture and mixture. Iron uptake and reducing capacity have been shown to be 


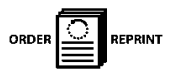

Fe Nutrition of Peanut Intercropped with Maize

closely related to root diameter and root hair occurrence. ${ }^{[28]}$ In our experiment, a higher ferric reduction capacity for a longer time period and the relatively fine root morphology of peanut roots in mixture may have assisted in the mobilization of sparingly soluble $\mathrm{Fe}(\mathrm{III})$ compounds from the apoplasmic $\mathrm{Fe}$ pool or the growth medium so that the peanut plants remained green. Another possibility is that maize released phytosiderophores into the rhizosphere of peanut and helped to make much more root apoplasmic Fe available to peanut in mixture than in monoculture. It has been demonstrated that the apoplasmic Fe pool is more easily reduced than ferric precipitates for plants grown in calcareous soil, and only when this Fe pool was exhausted did the plants become increasingly chlorotic. ${ }^{[29]}$ Thus it is possible that peanut plants grown as mixed crops may have had higher apoplastic Fe concentration and be able to make more efficient use of the apoplasmic Fe pool than in monocropping.

\section{Role of Bacteria in the Rhizosphere of Peanut Intercropped with Maize in the Improvement of Iron Nutrition of Peanut}

It is well known that plant species can influence the micro-organisms on each other's roots when growing in mixtures. ${ }^{[30]}$ Different plant species ${ }^{[7,8]}$ and genotypes ${ }^{[9]}$ can differentially influence microbial populations in the rhizosphere. In our experiment the population densities of bacteria on peanut roots in mixture were lower than in monoculture (Figs. 2(c), (d) (arrow) and 3). Furthermore, the mucigel layer on the root surface of the peanut in mixture with maize was much thicker than in monoculture (Fig. 2(c), m). The mucigel may not only mould to the surface of soil particles, but may also diffuse into aggregates to bring soil and root surfaces into intimate contact. In such a zone, the apparent free space and the soil solution become one and contribute the circumstances that facilitate reduction and subsequent uptake of $\mathrm{Mn}$ and $\mathrm{Fe}^{\left[{ }^{[31]}\right.}$ Thus, the thicker mucigel layer on peanut roots grown with maize compared to monocropping, may have promoted Fe mobilization and uptake.

It is clear that the efficacy of phytosiderophores for peanut Fe uptake will depend on the concentration produced in soils, their resistance to microbial degradation, their chelation properties with competing metals, and their capacity to resist being stripped of Fe by other chelators or by microbes. Although not yet tested, there are grounds for suspecting that the rate of microbial decomposition and/or inactivation of root exudates of maize were different in monoculture and mixture. Phytosiderophore-Fe chelates are easily reduced and taken up by dicots, ${ }^{[32,33]}$ but it is taken up at a much higher rate in monocots through the specific uptake system of Strategy II plants. ${ }^{[34]}$ Fe-chelating exudates of maize (phytosiderophores) are suspected of being readily decomposed by microorganisms. ${ }^{[35]}$ At the same time, because mucilage may contain high molecular 


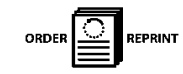

weight polysaccharides and polyuronides as well as some proteins and traces of phenolic compounds, it may be readily decomposed by micro-organisms for their growth. ${ }^{[31]}$ This may offer a possible explanation for the reduced abundance of micro-organisms in the rhizosphere of peanut in mixture associated with enhanced Fe nutrition of peanut in our experiment. We suggest that the fewer micro-organisms on peanut roots in mixture may not only lead to a decrease in the degradation of phytosiderophores exuded by maize, but also decrease the degradation of the thicker mucigel layer on peanut roots in mixture with maize. The thicker mucigel layer on peanut roots and greater potential accumulation of maize phytosiderophores in the rhizosphere of peanut in mixture with maize may have aided $\mathrm{Fe}$ accumulation in the root apoplast of peanut and subsequent uptake. We have not demonstrated these mechanisms unequivocally and they require further study.

Despite the wealth of information on siderophores, there is still considerable debate as how they function in the plant rhizosphere and the degree to which they accumulate in soils, especially as to how plants and microorganisms interact in their mutual problem of acquiring iron and the mechanisms that are used for iron acquisition from different iron sources. The community composition and activity of the microbial populations may control the rate of production and degradation of different siderophores, as well as the amount of $\mathrm{Fe}$ that is cycled through the turnover of microorganisms and root detritus. ${ }^{[36,37]}$ Under Fe stress conditions, high concentrations of siderophores can be produced by common soil microbes when cultured in low-Fe media. Siderophores are produced only by Fe-stressed micro-organisms and the premise that microbes often have multiple systems for $\mathrm{Fe}$ acquisition is the basis of the assumption that $\mathrm{Fe}$ chelates may control $\mathrm{Fe}$ availability in soil. Microbes (and possibly plants) may under certain conditions compete for $\mathrm{Fe}$ on the basis of siderophore type ${ }^{[38]}$ Microbial siderophores usually exhibit high stability constants and their Fe complexes are reduced at low potentials. ${ }^{\left[{ }^{[9]}\right.}$ Because of these properties, some results concluded that microbial siderophores are unlikely to be reduced by the reductase system on plant roots. ${ }^{[40]}$ Plants and microorganisms can compete for iron under certain conditions, although the extent to which this influences plant ecology in nature can be questioned. However, the extent to which plants rely on microbial siderophores for iron nutrition is questionable, since siderophores probably never occur at high concentration throughout the rhizosphere. ${ }^{[36,41]}$ In our research, peanut intercropping with maize could result in a change in the composition or quantity of root exudates in the rhizosphere of peanut which in turn could also significantly affect both the type and quantity of the various siderophores that are produced by different microbial populations. The bacterial microflora may play a role in the expression of tolerance to $\mathrm{Fe}$ deficiency of peanut in the intercropping 


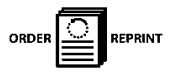

system. One possible explanation is that a much larger bacterial microflora in the rhizosphere of peanut in monocropping competes more strongly with the peanut plants for Fe, whereas a decrease in the rhizosphere bacterial microflora of intercopped peanut may reduce competition with peanut for Fe. We therefore suggest that changes in bacterial abundance in the rhizosphere of peanut in intercopping may be one of the mechanisms underlying differences in the $\mathrm{Fe}$ nutrition of peanut in different cropping systems. However, conventional plating techniques may enumerate only a small proportion of the bacterial species present in the soil and must be interpreted with caution.

The importance of siderophores in the ecology of bacteria is much less known. ${ }^{[36]}$ Further research is required to elucidate fully the relationship between the bacterial microflora and Fe nutrition in different cropping systems. Further characterization of the potential effects of micro-organisms in the rhizosphere of peanut in different cropping systems is currently in progress.

\section{ACKNOWLEDGMENTS}

We thank the National Natural Science Foundation of China and the Major State Basic Research Development Programme for financial support (Projects 30170185 and G1999011709), and Dr. D. E. Crowley of the Department of Environmental Sciences, University of California at Riverside, for valuable suggestions and comments on the paper.

\section{REFERENCES}

1. Zuo, Y.M.; Zhang, F.S.; Li, X.L.; Cao, Y.P. Studies on the improvement in iron nutrition of peanut by intercropping with maize on a calcareous soil. Plant Soil 2000, 220, 13-25.

2. Bienfait, H.F. Mechanisms in Fe-efficiency reactions of higher plants. J. Plant Nutr. 1988, 11, 605-629.

3. Marschner, H.; Treeby, M.; Römheld, V. Role of root-induced changes in the rhizosphere for iron acquisition in higher plants. Z. Pflanz. Bodenk. 1989, 152, 197-204.

4. Marschner, H.; Römheld, V.; Kissel, M. Different strategies in higher plants in mobilization and uptake of iron. J. Plant Nutr. 1986, 9, 695-713.

5. Tinker, P.B. The role of microorganisms in mediating and facilitating the uptake of plant nutrients from soil. Plant Soil 1984, 76, 77-91.

6. Darrah, P.R. The rhizosphere and plant nutrition: a quantitative approach. Plant Soil 1993, 156, 1-20. 


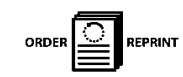

7. Lemanceau, P.; Corberand, T.; Gardan, L.; Latour, X.; Laguerre, G.; Boeufgras, J.M.; Alabouvette, C. Effect of two plant species, flax (Linum usitatissimum L.) and tomato (Lycopersicon esculentum mill), on the diversity of soilborne populations of fluorescent pseudomonads. Appl. Environ. Microbiol. 1995, 61, 1004-1012.

8. Wiehe, W.; Höflich, G. Survival of plant growth promoting rhizosphere bacteria in the rhizosphere of different crops and migration to noninoculated plants under field conditions in northeast Germany. Microbiol. Res. 1995, 150, 201-206.

9. Khanna, R.; Chandra, S.; Khanna, K.K. Rhizosphere microflora of triticale. Biological Memoirs 1993, 19, 111-121.

10. Takkar, P.N.; Kaur, N.P. $\mathrm{HCl}$ method for $\mathrm{Fe}^{2+}$ estimation to resolve iron chlorosis in plants. J. Plant Nutr. 1984, 7, 81-90.

11. Witham, F.H.; Blaydes, D.F.; Devlin, R.M. Experiments in Plant Physiology; Van Nostrand Reinhold: New York, NY, 1971; 55-58.

12. Newman, E.I. A method of estimating the total length of root in a sample. J. Appl. Ecol. 1966, 3, 139-145.

13. Landsberg, E.C. Function of rhizodermal transfer cells in the Fe stress response mechanism of Capsicum annuum L. Plant Physiol. 1986, 82, 511-517.

14. Marschner, H.; Römheld, V.; Kissel, M. Localization of phytosiderophore release and of iron uptake along intact barley roots. Physiol. Plantarum 1987, 71, 157-162.

15. Brown, J.C.; Jolley, V.D. Plant metabolic responses to iron deficiency stress. BioScience 1989, 39, 546-551.

16. Mori, S.; Nishizawa, N.; Kawai, S.; Sato, Y.; Takagi, S. Dynamic state of mugineic acid and analogous phytosiderophores in Fe-deficient barley. J. Plant Nutr. 1987, 10, 1003-1011.

17. Takagi, S.I.; Kamei, S.; Yu, M.H. Efficiency of iron extraction from soil by mugineic acid family phytosiderophores. J. Plant Nutr. 1988, 11, 643-651.

18. Zhang, F.; Treeby, M.; Römheld, V.; Marschner, H. Mobilization of iron by phytosiderophores as affected by other micronutrients. Plant Soil 1990, 130, 173-178.

19. Ma, J.F.; Nomoto, K. Inhibition of mugineic acid-ferric complex uptake in barley by copper, zinc and cobalt. Physiol. Plantarum 1993, 89, 331-334.

20. Brown, J.C.; Ambler, J.E. Iron stress response in tomato (Lycopersicon esculentum). 1. Sites of Fe reduction, absorption and transport. Physiol. Plantarum 1974, 31, 221-224.

21. Römheld, V.; Marschner, H. Mechanism of iron uptake by peanut plants. I. Fe(III) Reduction, chelate splitting, and release of phenolics. Plant Physiol. 1983, 71, 949-954. 


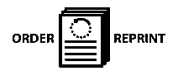

Fe Nutrition of Peanut Intercropped with Maize

22. Römheld, V.; Muller, C.; Marschner, H. Localization and capacity of proton pumps in roots of intact sunflower plants. Plant Physiol. 1984, 76, 603-606.

23. Mozafar, A.; Oertli, J.J. A critical evaluation of iron mobilization mechanisms with special reference to the contact effect phenomenon. J. Plant Nutr. 1986, 9, 759-780.

24. Mozafar, A.; Oertli, J.J. Contact-uptake of iron from vermiculite by maize. J. Plant Nutr. 1988, 11, 1217-1225.

25. Römheld, V.; Marschner, H. Iron deficiency stress induced morphological and physiological changes in root tips of sunflower. Physiol. Plantarum 1981, 53, 354-360.

26. Landsberg, E.C. Transfer cell formation in the root epidermis: a prerequisite for Fe efficiency? J. Plant Nutr. 1982, 5, 415-432.

27. Landsberg, E.C. Transfer cell formation in sugar beet roots induced by latent Fe deficiency. Plant Soil 1994, 165, 197-205.

28. Bavaresco, L.; Fregoni, M.; Fraschini, P. Investigations on iron uptake and reduction by excised roots of different grapevine rootstocks and a V. vinifera cultivar. In Proc. 5th Int. Symp. on Iron Nutrition and Interactions in Plants; Kluwer: Dordrecht, 1991; 139-143.

29. Bienfait, H.F.; van der Briel, W.; Mesland-Mul, N.T. Free space iron pools in roots: generation and mobilization. Plant Physiol. 1985, 78, 596-600.

30. Christie, P.; Newman, E.I.; Campbell, R. Grassland species can influence the abundance of microbes on each other's roots. Nature Lond. 1974, 250, $570-571$.

31. Uren, N.C. Mucilage secretion and its interaction with soil, and contact reduction. Plant Soil 1993, 155, 79-82.

32. Hopkins, B.G.; Jolley, V.D.; Brown, J.C. Plant utilization of iron solubilized by oat phytosiderophore. J. Plant Nutr. 1992, 15, 1599-1612.

33. Jolley, V.D.; Brown, J.C. Genetically controlled uptake and use of iron by plants. In Biochemistry of Micronutrients in the Rhizosphere; Manthey, J.A., Crowley, D.E., Luster, D.G., Eds.; CRC Press: Boca Raton, LA, 1994; 251-266.

34. Bar-Ness, R.; Chen, Y.; Hader, Y.; Marschner, H.; Römheld, V. Siderophores of Pseudomonas putida as an iron source for dicot and monocot plants. In Proc. 5th Int. Symp. on Iron Nutrition and Interactions in Plants; Kluwer: Dordrecht, 1991; 271-281.

35. von Wiren, N.; Römheld, V.; Shiori, T.; Marschner, H. Competition between micro-organisms and roots of barley and sorghum for iron accumulated in the root apoplast. New Phytol. 1995, 130, 511-521.

36. Crowley, D.E.; Pinton, R.; Varanini, Z.; Nannipieri, P. Function of siderophores in the plant rhizosphere. In The Rhizosphere. Biochemistry and Organic Substances at the Soil-Plant Interface; Marcel Dekker: New York, 2001; 223-262. 


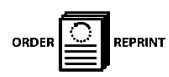

2110

Zuo et al.

37. Crowley, D.E.; Wang, Y.C.; Reid, C.P.P.; Szaniszlo, P.J. Mechanisms of iron acquisition from siderophores by microorganisms and plants. Plant Soil 1991, 130, 179-198.

38. Leong, J. Siderophores: their biochemistry and possible role in the biocontrol of plant pathogens. Ann. Rev. Phytopathol. 1986, 24, 187-209.

39. Raymond, K.N.; Muller, G.; Matzanke, B.F. Complexation of iron by siderophores: a review of their solution and structural chemistry and biological function. Topics in Current Chemistry 1984, 123, 49-102.

40. Bienfait, H.F.; Bino, R.J.; van der Bliek, A.M.; Duivenvoorden, J.F.; Fontaine, J.M. Characterization of ferric reducing activity in roots of Fedeficient Phaseolus vulgaris. Physiol. Plantarum 1983, 59, 196-202.

41. Bossier, P.; Verstraete, W. Detection of siderophores in soil by direct bioassay. Soil Biol. Biochem. 1986, 18, 481-487. 